\title{
FORMATION OF NONTRONITE FROM OXIDATIVE DISSOLUTION OF PYRITE DISSEMINATED IN PRECAMBRIAN FELSIC METAVOLCANICS OF THE SOUTHERN IBERIAN MASSIF (SPAIN)
}

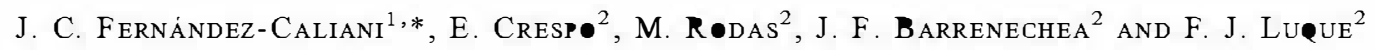 \\ ${ }^{1}$ Departamento de Geología, Facultad de Ciencias Experimentales, Universidad de Huelva, 21071 Huelva, Spain \\ 2 Departamento de Cristalografía y Mineralogía, Facultad de Geología, Universidad Complutense de Madrid,
} 28040 Madrid, Spain

\begin{abstract}
This paper describes a rare occurrence of nontronite associated with sulfide-bearing felsic metavolcanics, providing evidence of colloidal deposition in open spaces as result of a low-temperature water-rock interaction. Microbotryoidal masses of green nontronite with impurities of kaolinite, illite, barite, amorphous silica and iron oxyhydroxides are found as vein and cavity fillings in deeply kaolinized rhyolites and rhyolitic tuffs of Precambrian age, at Oliva de Mérida in SW Spain. Clay mineral characterization has been carried out by X-ray diffraction, infrared spectroscopy, thermal analysis, analytical electron microscopy and stable isotope (oxygen and hydrogen) analysis. Nontronite was formed under low-temperature alteration conditions, from a continuous sequence of reactions and aqueous solution compositions, involving two basic processes that acted in concert: oxidative dissolution of pyrite and hydrolysis of $\mathrm{K}$-feldspar. After acidity neutralization, dissolved silica released by incongruent dissolution of K-feldspar reacted with ferric sulfate derived from pyrite oxidation to form nontronite under oxidizing conditions, in the presence of relatively warm meteoric water.
\end{abstract}

Key Words-Felsic Metavolcanics, K-feldspar Hydrolysis, Nontronite, Pyrite Oxidation, Smectite, Spain, Weathering.

\section{INTRODUCTION}

Nøntronite is a 2:1 swelling phyllesilicate in which tetrahedral sites are predeminantly eccupied by $\mathrm{Si}$ cations, but søme replacement of $\mathrm{Si}$ by $\mathrm{Al}$ and $\mathrm{Fe}^{3+}$ can $\bullet c c u r$, whereas møst $\bullet$ the $\bullet c t a h e d r a l$ sites are filled by $\mathrm{Fe}^{3+}(>1.0$ cation per half unit-cell according to Güven, 1988), with minør amounts of Al. Thus, the general structural formula for nentrenite can be written

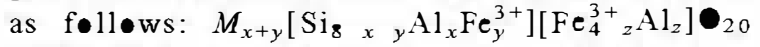
$(\bullet)_{4} \cdot n \mathrm{H}_{2} \bullet$, where $M$ refers to exchangeable interlayer cations. Nontronite is regarded, therefore, as the ferric end-member of diectahedral smectites. Details on its structure and crystal chemistry are given in Güven (1988) and references therein.

Althøugh nøntronite has been studied extensively, it continues to attract a high level of research interest, especially for interplanetary life. Indeed, this ferric smectite is relevant to the search for life on planets like Mars, •wing to its high $\mathrm{Fe}$ content and because it can be a pøtential søurce of water (Frøst et al., 2002).

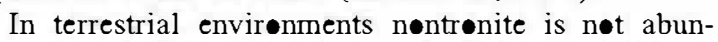
dant. However, it is commen in both oceanic and continental envirønments and often •ccurs as an authigenic clay mineral in recent submarine sediments, formed by direct precipitation from hydrothermal fluids

* E-mail address of corresponding author: caliani@uhu.es discharged from active sea-fløer spreading centres (Keeling et al., 2000). For instance, it is a typical clay mineral of deep-sea sediments frem marine white smøker chimneys of the Red Sea, Galapages rift, Mariana trøugh, and Juan de Fuca ridge, ameng •ther hydrothermal systems (Cøle and Shaw, 1983; Murnane and Clague, 1983; Singer et al., 1984; Singer and Stoffers, 1987; Kohler et al., 1994). In this eceanic

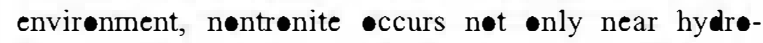
thermal vent •penings, but als on the sea-fløer by alteration of glassy balsaltic lava flows, as well as micrøbially-mediated løw-temperature reaction of irøn

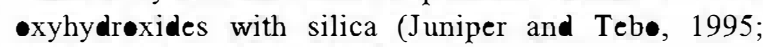
Ueshima and Tazaki, 2001).

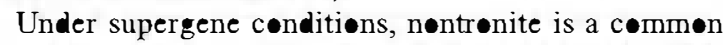
weathering product of basalts and ultramafic recks (e.g. Bender-K•ch et al., 1995). It is alsø found in highly weathered metamerphic rocks, such as schists, gneisses and amphibelites (Keeling et al., 2000). Morevver, it has been reported in felsic velcanics either as an alteration preduct of Fe-rich silicates (Shenk and Armbruster, 1985), or around rootless fumarøles by leaching and dissolution of rhy litic ignimbrites (Reyes and Read, 2002).

In this paper we describe a new eccurrence of nøntronite in Spain which is asseciated with sulfidebearing felsic v $\bullet$ lcan $\bullet$-sedimentary recks. We suggest a

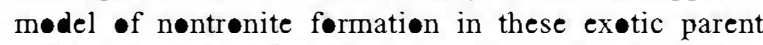
recks based on mineraløgical and geøchemical data, together with field and petrøgraphic •bservations. 


\section{GEOLOGICAL SETTING}

Nontronite occurrences are located near Oliva de Mérida, $\sim 20 \mathrm{~km}$ to the $\mathrm{SE}$ from the roman city of Mérida, in the province of Badajoz (SW Spain). From a geological standpoint, the mineralization is found in association with a volcano-sedimentary sequence of Middle-Upper Riphean age (Figure 1), at the Precambrian basement of the Ossa-Morena Zone, in the SW margin of the Iberian Massif (Gibbons and Moreno, 2002).

The volcano-sedimentary sequence is a succession of predominantly felsic metavolcanics (volumetrically, rhyolites are the most abundant) and volcanoclastic rocks (mainly rhyolitic tuffs and tuffaceous shales) interbedded with metasediments (schists, quartzites and pelitic gneisses), mafic metavolcanics and amphibolites. Volcanic-hosted disseminated pyrite appears within the volcano-sedimentary package, in close spatial relationship to the felsic rocks. Supergene weathering oxidized the sulfides forming numerous goethite concretions and abundant ferruginous surface coatings.

According to IGME (1988), the Precambrian materials constitute the core of the Oliva de Mérida anticlinorium, and form part of the Tentudía-Montemolín series (Eguiluz et al., 1984), belonging to the Alange Unit of the ObejoValsequillo-Puebla de la Reina domain. All these rocks were affected by Cadomian tectonothermal events (Quesada, 1990) and later they were deformed and metamorphosed during the Variscan orogeny.

\section{MATERIALS AND ANALYTICAL METHODS}

A cm-scale grid was used to collect clayey samples from the outcrop examined in the field (section A-B in Figure 1). In addition, a series of representative samples of the host rocks was collected for petrographic analysis.

Mineralogical characterization was performed using a combination of analytical methods including transmitted-light optical microscopy, X-ray diffraction (XRD), Fourier transform infrared spectroscopy (FTIR), differential thermal and thermogravimetric analysis (DTA-TGA), scanning electron microscopy (SEM), energy dispersive X-ray spectroscopy (EDS), and stable isotope (oxygen and hydrogen) analysis.

$\mathrm{X}$-ray diffraction was used to determine the bulk composition of the samples, after gentle grinding and

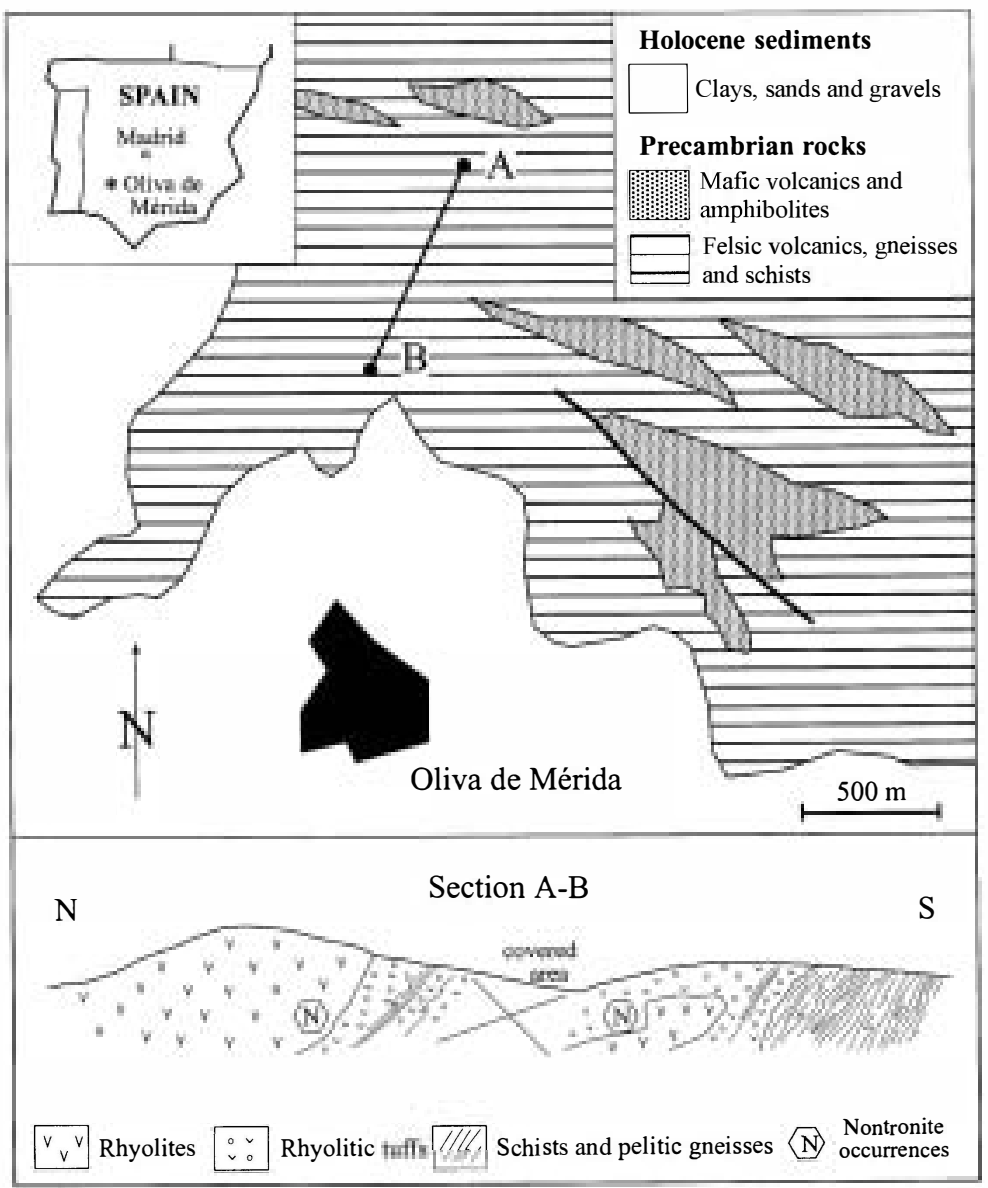

Figure 1. Generalized geological map of the Oliva de Mérida area depicting a section with the nontronite occurrences within a volcano-sedimentary sequence of Middle-Upper Riphean age. 


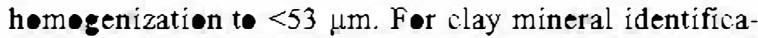
tion, carefully hand-picked samples were disaggregated in an ulmasonic bath. From these samples, oriented aggregates of the $<2 \mu \mathrm{m}$ size fraction were obtained by sedimentation from an aqueous suspension, pipetted ont glass slides and dried. The oriented films were solvated with ethylene glycol and subjected to thermal weament at $550^{\circ} \mathrm{C}$ for $2 \mathrm{~h}$ (Moore and Reynelds, 1997). The XRD patterns of random powders and oriented aggregates were collected using Ni-filtered CuK $\alpha$ radiation with a Siemens 500 powder diffractometer equipped with a graphite monochromater. The XRD patterns were recorded with a microcomputer using the Siemens SOCABIM Diffract AT3.3 seftware.

The IR abserbance spectra were recorded in the middle IR region (spectral range between 400 and $4000 \mathrm{~cm}^{1}$ ) on a Nicolet, 20SXC FTIR spectrometer, using pressed pellets containing $3 \mathrm{mg}$ of sample and $300 \mathrm{mg} \mathrm{KBr}$. The TA-TGA curves were obtained with a Seik 3200 instrument operating at a heating rate constant of, $20^{\circ} \mathrm{C} / \mathrm{min}$, from ambient temperature $\left(25^{\circ} \mathrm{C}\right)$ to $1000^{\circ} \mathrm{C}$, in a static air amesphere.

Fragments of each sample were mounted on stubs, coated with carbon, and examined by SEM in secondary electron mode in a Je@l JSM-541 microscope, operated at an accelerating voltage of $15 \mathrm{kV}$. Quantitative chemical analyses were obtained by means of an Oxford Link system energy dispersive X-ray (EDS) analyzer coupled to the microscope.

The isotopic analyses were performed at the Stable Is otope Labøratery of Salamanca University, using a SMA series $\mathbf{I}$ spectrometer from VG Isotech. Oxysen was extracted following Clayton and Mayeda's (1963) technique by reaction with $\mathrm{ClF}_{3}$ (Borthwick and Harmon, 1982). Hydrogen was exwacted following the precedures of Gedfrey $(1,62)$.

\section{FIELD AND PETROGRAPHIC RELATIONSHIPS}

The nontronite eccurrences display a clear epigenetic relationship to porphyritic felsic rocks containing phenecrysts of quartz and K-feldspar (sanidine) enclosed in a glassy groundmass, often showing perlitic cracks. Subordinate amounts of sødic plagioclase, muscovite and rutile are alse present, and numerous scattered crystals of exidized pyrite eccur locally in the rhy litic matrix (Figure 2a). The felsic velcanics are embedded within a velcan-sedimentary framework in which finegrained rhyolitic tuffs and a sequence of predeminantly sulfide-bearing black schists and quartzites can be distinguished. Likewise, all these rocks show field and perographic evidence of extensive sulfide oxidization, such as veins and bands of mixed iron oxy-hydroxides and hematite pseudemerphous after pyrite crystals (Figure 3).

Bright apple green clayey material with a massive appearance $\bullet c c u r s$ together with dendritic aggregates of iron oxyhydroxides as surface coatings along the sides of fissures (Figure 2b). Mest of the mineralized fractures are oriented subvertically following the regional fracturing wend (mainly $\mathrm{N} 50^{\circ} \mathrm{E}$ and $\mathrm{N} 135^{\circ} \mathrm{E}$ ). Furthermere, small masses of green clay, up to several dm thick, are found as veins, patches and cavity fillings in deeply kalinized rhyolitic tuffs (Figure 2c). These felsic rocks are the main hest to the mineralization, although the distribution of minerals is controlled by fracturing.

\section{GENERAL CHARACTERIZATION}

XRD

The green clays are compesed of virtually pure smectite (Figure 4). The patterns of the eriented
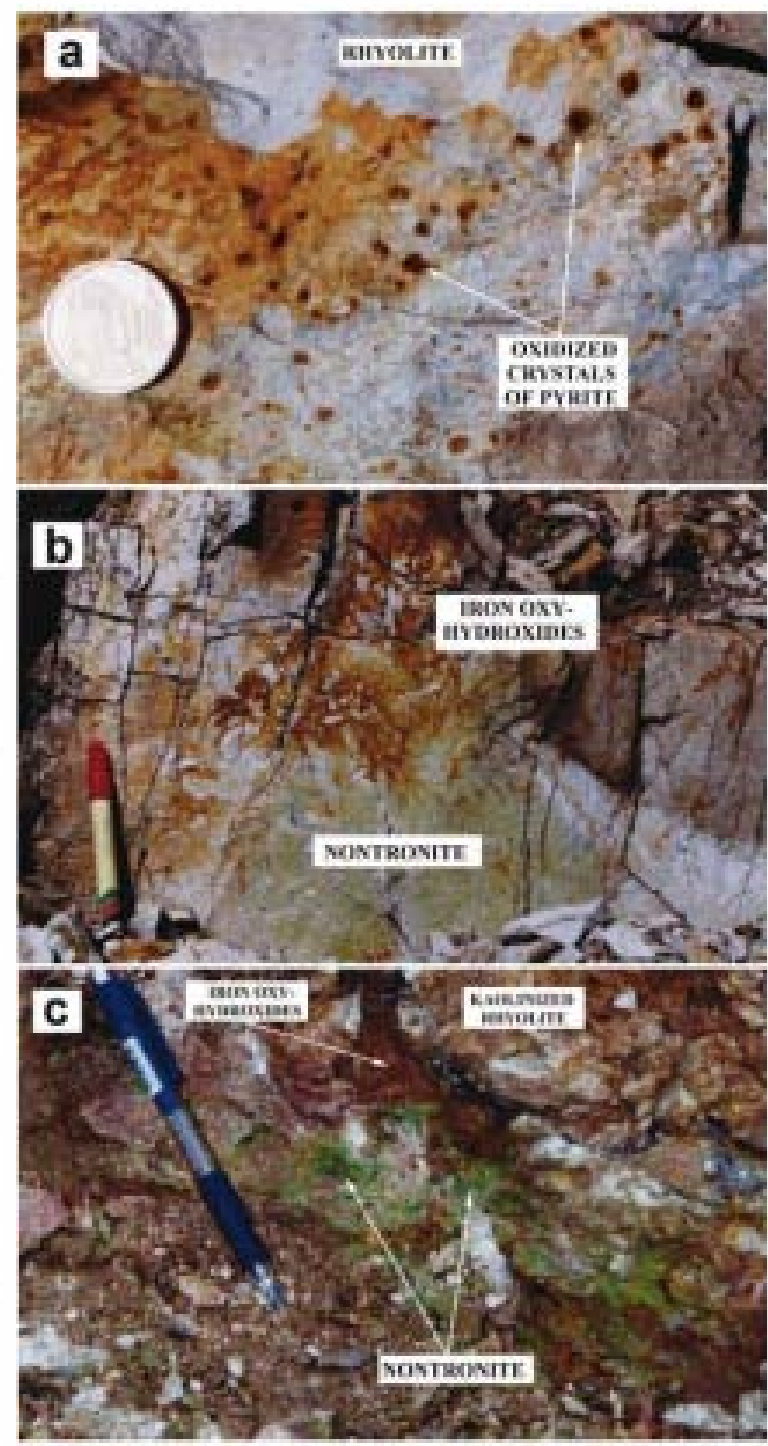

Figure 2. Field evidence of iron-sulfide exidation inrhy lite (a) and types of occurrences of the greenish nentronite: (b) nontronite and iron $\bullet x y$-hydroxides ceating fissure surfaces in rhy lite; (c) massive nentrenite infilling cavities in highly ka linized thy lite. 


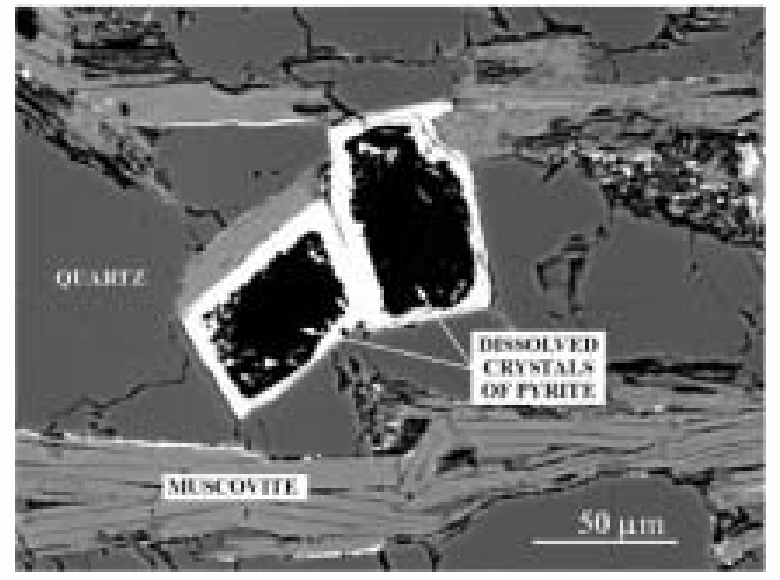

Figure 3. SEM-BSE image showing dissolved crystals of pyrite partially replaced by hematite in quartz-schist.

aggregates are similar and show a sharp and strong 001 reflection at $\sim 14 \AA$ in the air-dried mounts that shifted to $\sim 16.6 \AA$ after ethylene glycol solvation, and to $\sim 9.6 \AA$ after heating at $550^{\circ} \mathrm{C}$, indicating the presence of a highly crystalline smectite (Biscaye index = $0.954-0.992)$. The smectite contains a double layer of water molecules and exchangeable divalent cations in the interlayer space.

The $b_{0}$ parameter values $(9.048-9.096 \AA)$ derived from the position of the 060 reflection in the nonoriented powder XRD patterns are within the dioctahedral range of smectites. Brigatti (1983) and Köster et al. (1999) observed a linear correlation between the $b$ unitcell dimension of dioctahedral smectites and the total

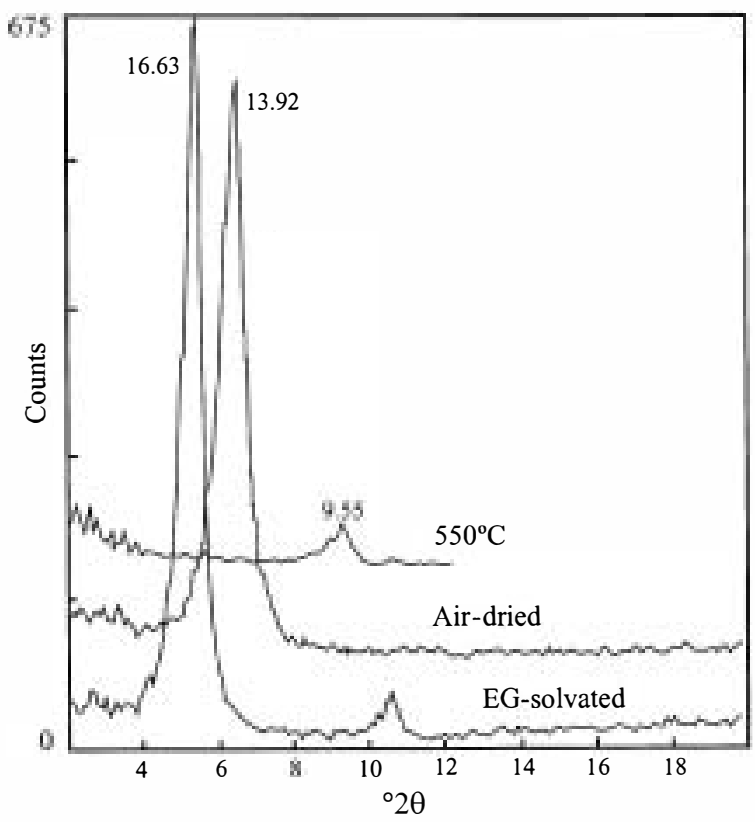

Figure 4. Typical XRD patterns for the oriented clay fraction of the Oliva de Mérida nontronite.

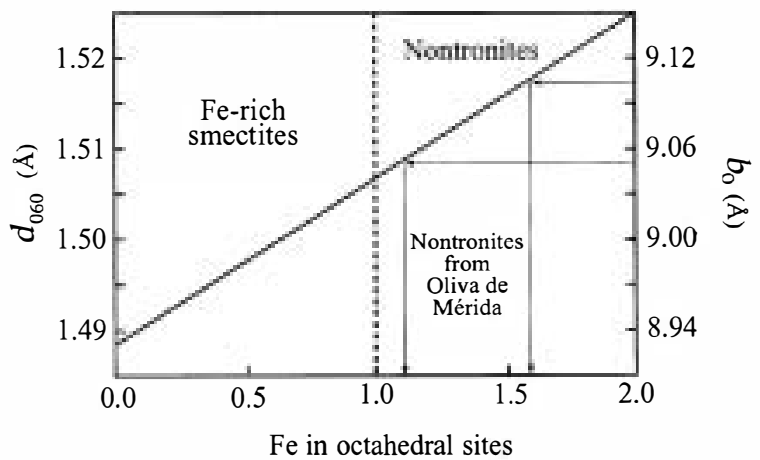

Figure 5. Nontronite $b$ unit-cell dimension as measured by XRD $v s$. octahedral Fe content. Regression line established by Brigatti (1983).

number of $\mathrm{Fe}^{3+}$ ions in octahedral sites. Accordingly, the measured $b_{0}$ values plotted on the line of regression fitted in Figure 5, are consistent with an octahedral $\mathrm{Fe}$ content $>1.0$ atom per half unit-cell. The smectite can be regarded, therefore, as a true nontronite on the basis of Güven's (1988) classification scheme for dioctahedral smectites.

\section{Infrared spectral analysis}

A typical IR absorbance spectrum of the nontronite (Figure 6) is characterized by two broad bands in the $\mathrm{OH}$-stretching region, centered at $\sim 3560$ and $3420 \mathrm{~cm}^{-1}$. The first absorption band is attributed to $\mathrm{Fe}^{3+}-\mathrm{OH}-\mathrm{Fe}^{3+}$ vibrations indicating an Fe-rich smectite while the second is typically due to water (Petit et al., 2002). A strong $\mathrm{Si}-\mathrm{O}$ stretching band appears at $1021 \mathrm{~cm}^{-1}$. The position of this band reflects little or no sustitution of $\mathrm{Si}$ by $\mathrm{Fe}^{3+}$ in the tetrahedral sheets (Goodman et al., 1976). In the OH-bending region, three weak bands were observed at 864,814 and $678 \mathrm{~cm}^{-1}$, which can be assigned to the $\mathrm{Fe}^{3+} \mathrm{Fe}^{3+}(\mathrm{OH})$ unit of nontronite (Russell and Fraser, 1994; Koster et al., 1999).

\section{Thermal analysis}

The DTA-TGA pattern shown in Figure 7 illustrates the thermal decomposition of a typical nontronite

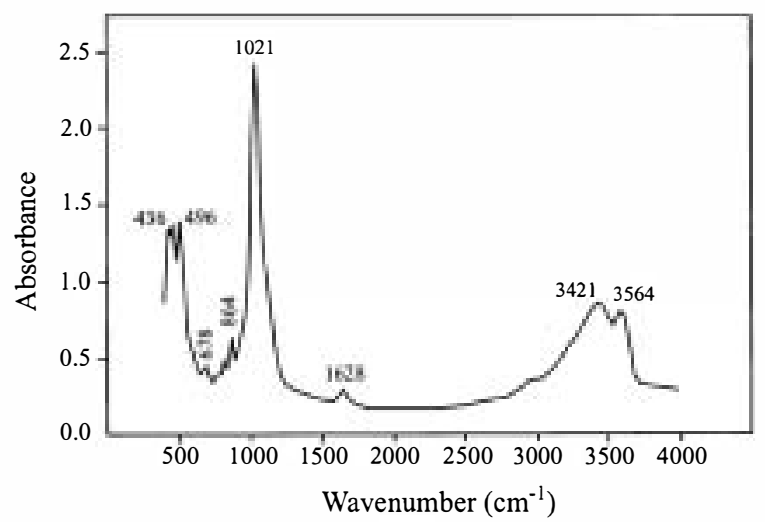

Figure 6. IR spectrum of Oliva de Mérida nontronite. 
sample. The first endothermic peak was observed at $90^{\circ} \mathrm{C}$, and it is attributed to the loss of adsorbed water. As a result of the water desorption, a loss of $13.4 \%$ in weight occurred. The dehydroxylation endothermic effect took place at $470^{\circ} \mathrm{C}$, and the weight loss during the dehydroxylation process was $5 \%$. The analyses show that the nontronite from Oliva de Mérida has a thermal behavior similar to, but less complex than, nontronite described at other localities (Ding and Frost, 2002), although the less complex pattern could be a consequence of different heating ratios. For instance, Ding and Frost (2002) carried out the controlled rate thermal analysis operating at much slower heating rate $\left(2^{\circ} \mathrm{C}\right)$, thus obtaining two overlapping dehydroxylation steps.

The observed dehydroxylation temperature is consistent with the measured $b$ unit-cell dimension (Figure 8), and also with the Fe content inferred by XRD, according to the regression equation given by Brigatti (1983).

\section{Analytical scanning electron microscopy}

The SEM images (Figure 9) show that massive nontronite is generally formed by microcrystalline aggregates consisting of lath-shaped crystals that often split into fine fiber-like particles (Figure 9a). Ribbons and delicate filaments of nontronite were also observed. The most conspicuous feature is the occurrence of globular or spherulitic aggregates forming a microbotryoidal texture (Figure 9b). The spherulites $(150-200 \mu \mathrm{m}$ in diameter) are made up of fibrous nontronite crystals (up to $100 \mu \mathrm{m}$ in length) radiating from a common core.

Although the nontronite samples are nearly monomineralic, some ancillary phases were identified by SEM-EDS, such as kaolinite, which usually occurs as lath-like particles within the core of the spherulites (Figure 9c), mica, quartz, feldspars, poorly crystalline iron oxy-hydroxides, amorphous silica and clustered euhedral crystals of barite (Figure 9d).

In order to approximate the chemical composition of the smectite, chemical analyses by EDS were obtained from selected individual particles. The number of ions was calculated on the basis of 24 anions per formula

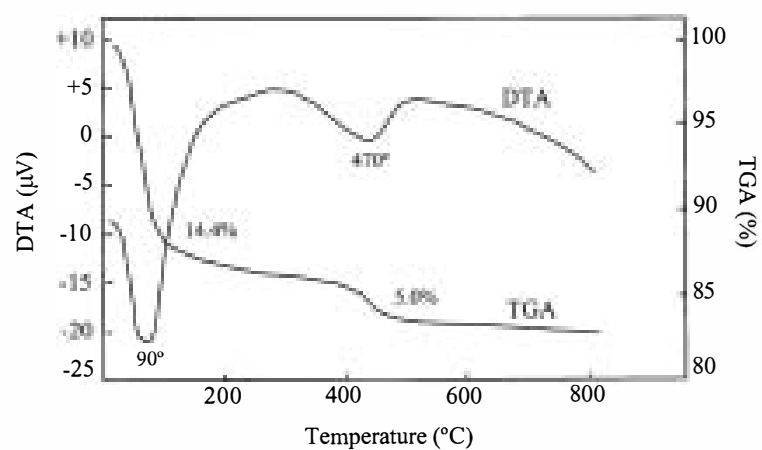

Figure 7. DTA-TGA diagram showing the endothermic reactions and weight loss found for the Oliva de Mérida nontronite. from the weight percentages of the major constituent oxides, which were obtained by converting the X-ray spectrum to a quantitative analysis, making appropriate corrections (quantitative method ZAF). The results confirmed the nontronitic character of the smectites the number of measured $\mathrm{Fe}^{3+}$ ions being $\sim 1.5$ per half unitcell. Nevertheless, taking into account the $\mathrm{Fe} / \mathrm{Fe}+\mathrm{Al}+\mathrm{Mg}$ ratio (Figure 10), as derived from the number of ions calculation, significant compositional variations can be inferred within the ferric member of the beidellitenontronite series. Minor amounts of $\mathrm{Ca}(<1 \mathrm{wt} . \% \mathrm{CaO})$, as detected by SEM-EDS, are present as exchangeable cation in the interlayer space, as previously deduced by XRD.

\section{Stable isotope analysis}

The stable isotope ratios of hydrogen $(\mathrm{D} / \mathrm{H})$ and oxygen $\left({ }^{16} \mathrm{O} /{ }^{18} \mathrm{O}\right)$ of a representative nontronite sample are -85.7 and $+16.3 \%$, respectively, relative to SMOW. It can be assumed that nontronite has retained its original isotopic composition because no post-formational process is evident from field and petrographic relations. As shown in Figure 11, the $\delta \mathrm{D}$ value plotted against the $\delta \mathrm{O}$ value depicts a point in the supergene field (on the right of the $\mathrm{S} / \mathrm{H}$ line), close to the kaolinite line, thus indicating that the nontronite mineralization was formed in equilibrium with meteoric waters (Sheppard and Gilg, 1996).

Clay minerals in low-temperature environments record the $\delta \mathrm{D}$ and $\delta \mathrm{O}$ values and temperature of the waters from which they formed because isotopic exchange rates are very slow (Kyser, 1987).

The oxygen isotope composition of water with which nontronite formed under equilibrium conditions can be calculated from the following equation, derived by Delgado and Reyes (1996):

$$
\begin{aligned}
\delta \mathrm{O}_{\text {water }}=-19.25+0.125 \delta \mathrm{D}_{\text {sm }}+ & \\
( & \left(12.33 \delta \mathrm{O}_{\mathrm{sm}}-1.54 \delta \mathrm{D}_{\mathrm{sm}}+252.2\right)^{1 / 2}
\end{aligned}
$$

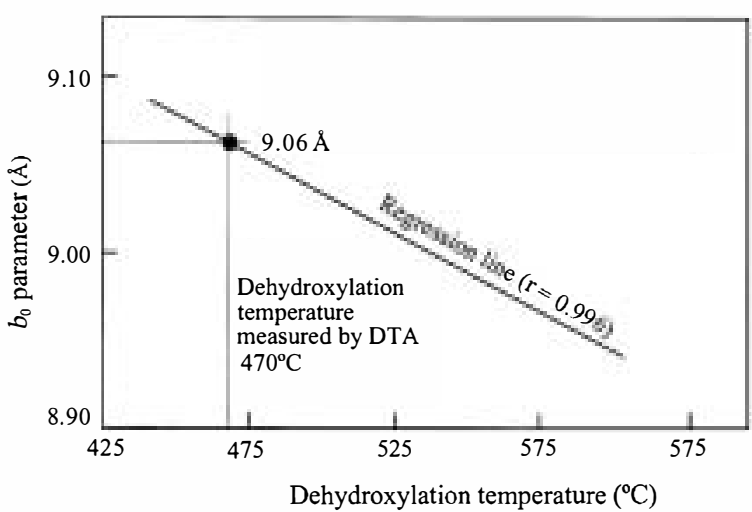

Figure 8. Dehydroxylation temperature of nontronite as determined by DTA vs. $b$ unit-cell dimension. Regression equation proposed by Brigatti (1983). 

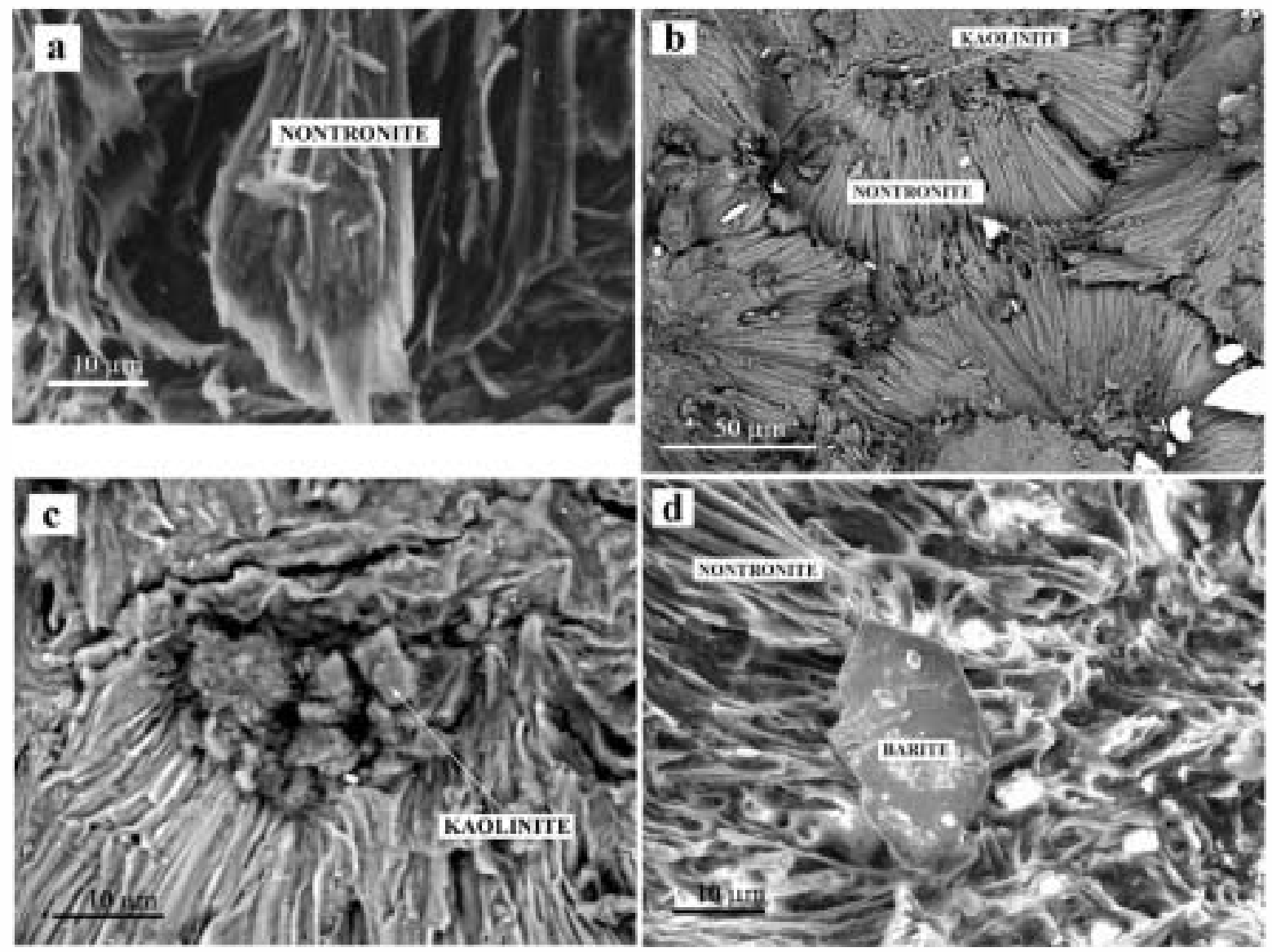

Figure 9. SEM-BSE images of nontronite samples showing: (a) lath-shaped crystals splitting into fine fiber-like morphologies; (b) spherulitic aggregates forming a microbotryoidal texture; (c) kaolinite pockets within the spherulites; (d) euhedral crystals of barite disseminated in the nontronite clays.

In this case, the $\delta \mathrm{O}$ value obtained for the water is $-4.9 \%$. Taking into account that hydrogen and oxygen isotope compositions of the meteoric water are corre-

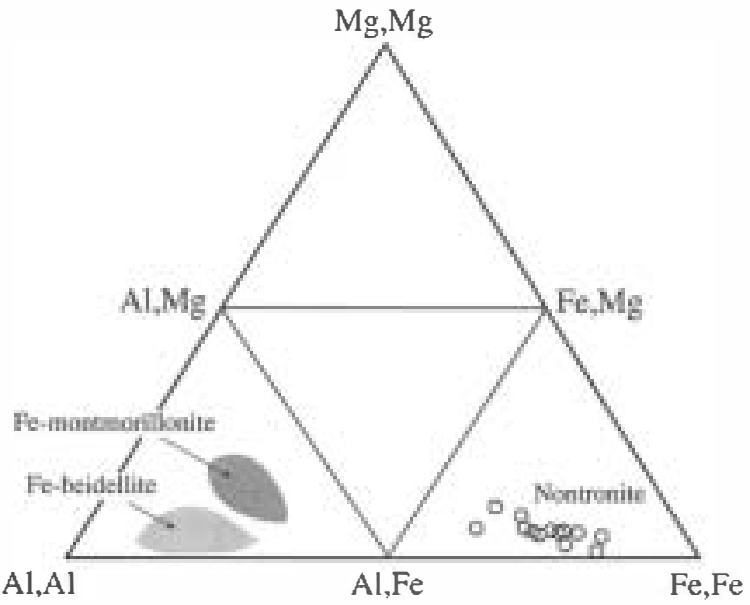

Figure 10. Projection on smectite compositional diagram (Güven, 1988) of the atomic proportions of $\mathrm{Fe}, \mathrm{Al}$ and $\mathrm{Mg}$ obtained from selected chemical analyses performed by SEMEDS on individual nontronite crystals. lated by means of the global meteoric water line equation (Craig, 1961):

$$
\delta \mathrm{D}=8 \delta \mathrm{O}+10
$$

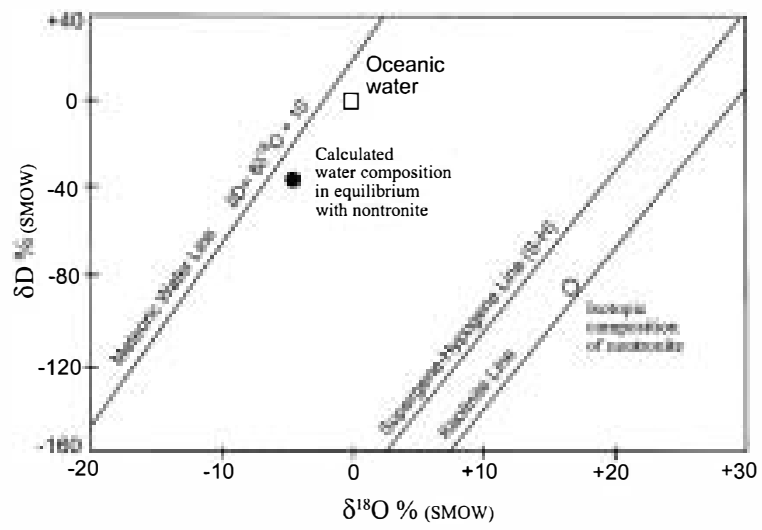

Figure 11. Hydrogen and oxygen isotope ratios of a representative nontronite sample and calculated isotope composition of water in equilibrium with nontronite. The meteoric water line (Craig, 1961), kaolinite weathering line (Savin and Epstein, $1970)$ and supergene/hypogene $(\mathrm{S} / \mathrm{H})$ line are given for reference. 
the od value calculated for water is $-29.2 \%$. The results are in the range of these of the present-day rainwater values (Alley and Cuffey, 2001).

Lastly, in erder to censtrain the temperature of nontrønite formation, we have used the equation derived by Delgade and Reyes (1996) for smectite which -riginated in epen systems with high water-røck ratiøs and relatively low temperatures:

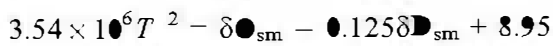

thus $\bullet$ btaining a temperature of $\sim 40^{\circ} \mathrm{C}$. Accerdingly, the nontronite mineralization was formed from the weathering - $f$ the felsic metavelcanics under low-temperature alteration conditions. The age of weathering is uncertain because the Precambrian basement in SW Spain has been expesed to surface conditions since Late Carbenifereus times.

\section{NONTRONITE FORMATION}

Three basic stages can be prepesed in the nentrenite formation precess: (1) exidation of pyrite and generation - f acidic waters; (2) hydrelysis of K-feldspar and acid neutralization, and ( 3 ) precipitation of nentrenite.

Stage I: oxidative dissolution of pyrite and acid generation

Oxidative disselution of the pyrite hested in the felsic metavelcanics and black schists took place during the weathering in the presence of meteric water and excess -f free exygen, through the reaction:

$$
2 \mathrm{FeS}_{2}+7 \boldsymbol{\bullet}_{2}+2 \mathrm{H}_{2}-2 \mathrm{Fe}^{2+}+4 \mathrm{~S}_{4}^{2}+4 \mathrm{H}^{+}
$$

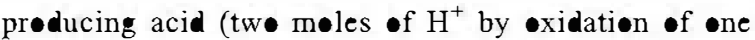
mele of pyrite) and leading to an increase in the chemical activities of $\mathrm{S}$ and Fe species in the aqueous selution. Because of the lowering of $\mathrm{pH}, \mathrm{Fe}^{2+}$ was exidized to $\mathrm{Fe}^{3+}$ according to the reaction:

$$
\mathrm{Fe}^{2+}+1 / 4 \mathrm{O}_{2}+\mathrm{H}^{+}-\mathrm{Fe}^{3+}+1 / 2 \mathrm{H}_{2} \mathrm{O}
$$

thus accelerating the pyrite exidation rate because ferric Fe replaces exygen as an exidizing agent. In fact, the -bserved pyrite exidation rate in the laberatery ranges between $1.08 \times 10^{15}$ and $1.8 \times 10^{14} \mathrm{~m} \bullet \mathrm{cm}^{2} \mathrm{~s}^{1}$, but these rates can be increased by about 100 times in the presence of ferric ir n in selution (Nichølsøn, 1994).

An assesment of acid generation of the sulfidebearing felsic recks can be made following Paktunc's (1999) appreach:

$$
A P=\frac{N_{\mathrm{s}} W_{\mathrm{a}} X_{\mathrm{s}}}{W_{\mathrm{s}}} \times 1
$$

where $A P$ is the acid petential of recks, $N_{\mathrm{s}}$ is the number - $f$ meles of sulfuric acid formed by the exidation of $1 \mathrm{~m} \bullet$ le $\bullet$ pyrite, $W_{\mathrm{a}}$ is the melecular weight $\bullet$ sulfuric acid, $W_{\mathrm{s}}$ is the melecular weight of pyrite, and $X_{\mathrm{s}}$ is the percentage of pyrite in the recks. Considering that the felsic metavelcanics centain $5 \%$ of pyrite on average, the acid petential was $\sim 82 \mathrm{~kg}$ of sulfuric acid equivalents per ton, which represent the volume of acid preduced by the pyrite exidation.

\section{Stage II: hydrolysis of alkali feldspar and acid} neutralization

As mentiøned previøusly, the masses of nentrenite

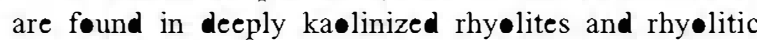
tuffs suggesting that hydrelysis of $\mathrm{K}$-feldspar •ccurred as result of acid reck drainage. For simplicity, the waterreck interaction precess can be described by incengruent disselution of the $\mathrm{K}$-feldspar to førm ka linite under acidic conditions, via the reaction:

$$
\begin{aligned}
2 \mathrm{KAlSi} \boldsymbol{\bullet}_{3}+\mathrm{H}_{2} \mathrm{~S}_{4}+9 \mathrm{H}_{2}- \\
\mathrm{Al}_{2} \mathrm{Si}_{2} \boldsymbol{\bullet}_{5}(\boldsymbol{H})_{4}+4 \mathrm{H}_{4} \mathrm{Si}_{4}+2 \mathrm{~K}^{+}+\mathrm{S}_{4}^{2}
\end{aligned}
$$

Mere silica is present in the $\mathrm{K}$-feldspar structure than is needed to form ka linite, therefore seme silica remains dissolved in the aqueous solution, together with $\mathrm{K}$ and sulfate iens.

Althøugh the disselution kinetics of K-feldspar are very slow (Blum and Stillings, 1995), the hydrelysis reaction consumed acid and became an impertant neutralization mechanism of the acidic water (tw moles of K-feldspar were necessary to neutralize •ne møle of sulfuric acid). Despite their løng-term buffering capacity, the felsic metavelcanics were alkaline en七ugh to neutralize the acidity of the selutions, as determined -n the basis of the net neutralizing petential (Paktunc, 1999).

The neutralizing potential (NP) can be calculated by:

$$
N \boldsymbol{P}=\frac{W a X_{\mathrm{i}}}{N_{\mathrm{i}} W_{\mathrm{i}}} \times 10
$$

where $W_{\mathrm{a}}$ is the melecular weight of sulfuric acid, $X_{\mathrm{i}}$ is the percentage of $\mathrm{K}$-feldspar in the felsic recks, $N_{\mathrm{i}}$ is the number of meles of $\mathrm{K}$-feldspar required to consume one mele of sulfuric acid, and $W_{\mathrm{i}}$ is the melecular weight $\bullet$ the $\mathrm{K}$-feldspar. Assuming that $\mathrm{K}$-feldspar is by far the mest abundant neutralizing phase in the felsic metavelcanics ( $60 \%$ n average), the bulk neutralizing petential calculated with this appreach is $\sim 105 \mathrm{~kg} \bullet \mathrm{f}$ sulfuric acid equivalent per ton.

Since the net neutralization potential (NNP), i.e. the balance between $N P$ and $A P$, is pesitive (NNP $=105-82$ $=23 \mathrm{~kg} / \mathrm{t} \bullet \mathrm{n}$ ), it can be concluded that the acidic solution was neutralized by the disselution of the K-feldspar.

\section{Stage III: precipitation of nontronite}

The combined reaction of acid generation by pyrite exidation and neutralization of the acidic selution by $\mathrm{K}$-feldspar disselutien prømeted a suitable envirønment

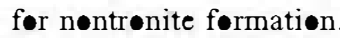

The majer chemical species disselved in the acidic aqueous selution from the abeve reactions were $\mathrm{Fe}^{3+}$, $\mathrm{K}^{+}, \mathrm{SO}_{4}^{2}$ and silica. After acidity neutralization, the disselved silica reacted with ferric sulfate derived frem 


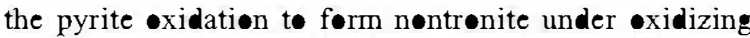
conditions. This reaction can be written as follews:

$$
\begin{aligned}
2\left(\mathrm{~S}_{4}\right)_{3} \mathrm{Fe}_{2}+8 \mathrm{Si} \boldsymbol{O}_{2}+ & 8 \mathrm{H}_{2}- \\
& \mathrm{Fe}_{4} \mathrm{Si}_{8} \mathbf{O}_{2} \cdot(\mathrm{OH})_{4}+6 \mathrm{H}_{2} \mathrm{SO}_{4}
\end{aligned}
$$

Significant cencentratiens of $\mathrm{Al}^{3+}$ may be disselved in acidic $(\mathrm{pH}<4)$ aqueous solutions during the weathering (e.g. Huang and Keller, 1972). It can be assumed therefore that some of the $\mathrm{Al}^{3+}$ disselved in the acidic

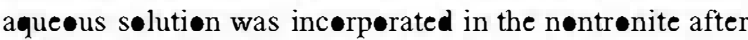
acidity neutralization

The velume of nentrenite mineralization was centrelled by the abundance of pyrite eriginally contained in the felsic recks, and the extent of K-feldspar dissølution. The disselution rate of the feldspar presumably determined the rate of the everall nontronite formation precess

It must be emphasized that nentronite started to precipitate ence the acidic water was neutralized. Harder (1976) demenstrated frem laberatery synthesis experiments that nentronite precipitation is achieved at surface temperatures with a $\mathrm{pH}>6$. Similarly, accompanying phases such as Fe exyhydrexides, amerpheus silica and illite were formed by way of the following reactions:

$$
\begin{aligned}
& \mathrm{Fe}^{3+}+2 \mathrm{H}_{2} \mathrm{O}-\mathrm{FeOOH}+3 \mathrm{H}^{+} \\
& \mathrm{H}_{4} \mathrm{SiO}_{4}-\mathrm{SiO}_{2} \text { (amorphous silica) }+2 \mathrm{H}_{2} \\
& \mathrm{~K}^{+}+3 \mathrm{Al}^{3+}+3 \mathrm{H}_{4} \mathrm{Si}_{4}-\mathrm{KAl}_{3} \mathrm{Si}_{3} \cdot(\bullet \mathrm{H})_{2}+1 \bullet \mathrm{H}^{+}
\end{aligned}
$$

With respect to the eccurrence of authigenic barite in the green clays, since $\mathbf{B a}$ is a commen miner element in the K-feldspar structure (e.geer et al., 1992), it can be readily explained by reaction of dissolved sulfate with Ba ions released inte selution frem the feldspar hydrolysis

The celløform texture suggests that nentrenite was

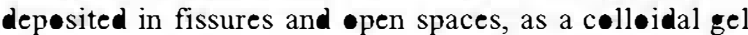
frem a percelating supersaturated fluid, and it develeped int larger and more ordered crystals with time. Hence, the structural discentinuities and other discrete pathflews of the felsic reck acted as channelways for relatively warm meteoric water alıng fault zønes. The formation temperature $\left(\sim 40^{\circ} \mathrm{C}\right)$ suggested by exygen is tope compesition is consistent with that of other nentronites formed under low-temperature alteration conditions $\left(<70^{\circ} \mathrm{C}\right)$ in both continental and eceanic envirenments (Köster et al., 1999).

The abøve genetic interpretation is based not $\bullet$ ly $\bullet$ the field, mineralegical and geechemical data presented here, but it is alse supperted by the experimental results - Decarreau et al. (1987) and Mizutani et al. (1991)

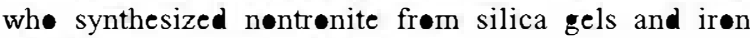
sulfate under exidizing conditions.

\section{C๑NCLUSI@NS}

The Precambrian sulfide-bearing felsic metavelcanics of the Oliva de Mérida underwent a low-temperature water-røck interaction precess, resulting in complete -xidation of pyrite and subsequent precipitation of nøntrønite through a sequence of reaction preducts and aque us selution compesitions. The nentrenite formatiøn precess can be summarized as f llews: (1) preduction of acidic aqueous solution frem interaction of meteoric water with sulfide-bearing felsic recks; (2) dissolution of $\mathrm{K}$-feldspar under the influx of acidic waters, release of cations and acidity neutralization; (3) nontronite precipitation through fissures of the felsic metavecanics from disselved compenents in selution, after acidity neutralization.

\section{ACKNOWLEDGMENTS}

We thank R. Rojas and M.A. Muro from the Instituto de Ciencia de Materiales (CSIC) of Madrid for their technical assistance with the FTIR and DTA-TGA analyses. We wish to thank also Prof. Ray Ferrell and Dr David Patrick for their helpful comments.

\section{REFERENCES}

Alley, R.B. and Cuffey, K.M. (2001) Oxygen and hydrogen isotopic ratios of water in precipitation: Beyond Paleothermometry. Pp. 527-553 in: Stable Isøt•pe Geochemistry (J.W. Valley and D.R. Cole, editors). Reviews in Mineralogy and Geochemistry, 43. Mineralogical Society of America, Washington, D.C.

Bender-Koch, C., Morup, S., Madsen, M.B. and Vistisen, L. (1995) Iron-containing weathering products of basalt in a cold, dry climate. Chemical Geøløy, 122, 109-1 19.

Blum, A.E. and Stillings, L.L. (1995) Feldspar dissolution kinetics. Pp. 291-351 in: Chemical Weathering Rates of Silicate Minerals (A.F. White and S.L. Brantley, editors). Reviews in Mineralogy, 31. Mineralogical Society of America, Washington, D.C.

Borthwick, J. and Harmon, R.S. (1982) A note regarding $\mathrm{ClF}_{3}$ as an alternative to $\mathbf{B r F}_{5}$ for oxygen isotope analysis.

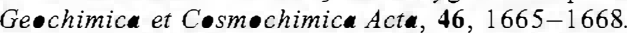

Brigatti, M.F. (1983) Relationships between composition and structure in Fe-rich smectites. Clay Minerals, 18, 177-186.

Clayton, R.N. and Mayeda, T.D. (1963) The use of bromine pentafluoride in the extraction of oxygen from oxides and

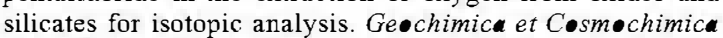
Acta, 27, 43-52

Cole, T.G. and Shaw, H.F. (1983) The nature and origin of authigenic smectites in some recent marine sediments. Clay Minerals, 18, 239-252.

Craig, H. (1961) Isotopic variations in meteoric waters. Science, 133, 1702-1703.

Decarreau, A., Bonnin, D., Badaut-Trauth, D., Couty, R. and Kaiser, P. (1987) Synthesis and crystallogenesis of ferric smectite by evolution of $\mathrm{Si}-\mathrm{Fe}$ coprecipitates in oxidizing conditions. Clay Minerals, 22, 207-223.

Deer, W.A., Howie, R.A. and Zussman, J. (1992) An

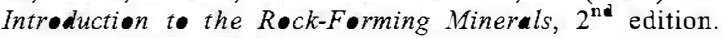
Longmans, Essex, UK

Delgado, A. and Reyes, E. (1996) Oxygen and hydrogen isotope compositions in clay minerals: A potential singlemineral geothermometer. Ge•chimic et Cosmøchimic Act a, 60, 4285-4289.

Ding, Z. and Frost, R.L. (2002) Controlled rate thermal analysis of nontronite. Therm $\bullet$ chimic Acta, 389, 185-193.

Eguiluz, L., Fernández, J., Garrote, A., Liñán, E. and Quesada, C. (1984) Sucesiones estratigráficas del anticlinorio 
Olivenza-Monesterio en la transversal Montemolín-

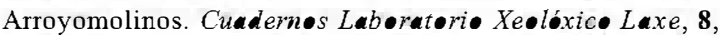
$117-123$.

Frost, R.L. Kloprogge, J.T. and Ding, Z. (2002) Near-infrared spectroscopy study of nontronites and ferruginous smectites.

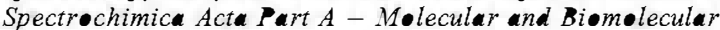

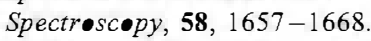

Gibbons, W. and Moreno, T. (2002) Introduction and overview. Pp. 1-6 in: The Geøløy of Spain (W. Gibbons and T. Moreno, editors). The Geological Society, London.

Godfrey, J.D. (1962) The deuterium content of hydrous minerals from the East Central Sierra Nevada and

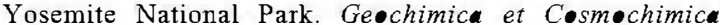
Acta, 26, 1215-1245

Goodman, B.A., Russell, J.D., Fraser, A.R. and Woodhams, F.W.D. (1976) A Mössbauer and IR spectroscopic study of the structure of nontronite. Clays and Clay Minerals, 24, 53-59.

Güven, N. (1988) Smectites. Pp. 497-559 in: Hydrous Phyll •silicates (Exclusive of Micas) (S.W. Bailey, editor). Reviews in Mineralogy, 19. Mineralogical Society of America, Washington, D.C.

Harder, H. (1976) Nontronite synthesis at low temperatures. Chemical Ge•løgy, 18, 169-180.

Huang, W.H. and Keller, W.D. (1972) Geochemical mechanics for the dissolution, transport, and deposition of aluminium in the zone of weathering. Clays and Clay Minerals, 20, $69-74$

IGME - Instituto Geológico y Minero de España (1988)

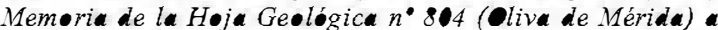
escala 1:50,000.59 pp. Ministerio de Industria y Energía, Madrid.

Juniper, S.K. and Tebo, M. (1995) Microbe-metal interactions and mineral deposition at hydrothermal vents. Pp. 219-253

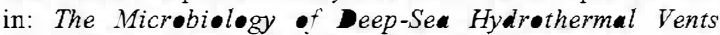
(D.M. Karl, editor). CRC Press, New York.

Keeling, J.L., Raven, M.D. and Gates, W.P. (2000) Geology and characterization of two hydrothermal nontronites from weathered metamorphic rocks at the Uley graphite mine, South Australia. Clays and Clay Minerals, 48, 537-548.

Köhler, B., Singer, A. and Stoffers, P. (1994) Biogenic nontronite from marine white smoker chimneys. Clays and Clay Minerals, 42, 689-701

Köster, H.M., Ehrlicher, U., Gilg, H.A., Jordan, R., Murad, E. and Onnich, K. (1999) Mineralogical and chemical characteristics of five nontronites and Fe-rich smectites. Clay Minerals, 34, 579-599.

Kyser, T.K. (1987) Equilibrium fractionation factors for stable

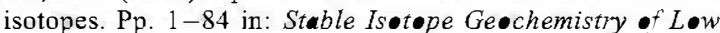
Temperature Fluids (T.K. Kyser, editor). Short Course Handbook, 13. Mineralogical Association of Canada, Toronto.

Mizutani, T., Fukushima, Y., Okada, A., Kamigaito, O. and Kobayashi, T. (1991) Synthesis of $1: 1$ and 2:1 iron phyllosilicates and characterization of their iron state by
Mössbauer spectroscopy. Clays and Clay Minerals, 39, $381-386$

Moore, D.M. and Reynolds, R.C. (1997) X-ray Diffraction and the Identification and Analysis of Clay Minerals. Oxford University Press, New York, $378 \mathrm{pp}$

Murnane, R. and Clague, D.A. (1983) Nontronite from a lowtemperature hydrothermal system on the Juan de Fuca Ridge. Eurth and Planetary Science Letters, 65, 343-352.

Nicholson, R.V. (1994) Iron-sulfide oxidation mechanisms: laboratory studies. Pp. 163-183 in: The Envirønmental Geochemistry of Sulfide Mine-ITastes (D.W. Blowes and J.L. Jambor, editors). Short Course Handbook, 22. Mineralogical Association of Canada, Toronto.

Paktunc, A.D. (1999) Characterization of mine wastes for prediction of acid mine drainage. Pp. 19-40 in: Envirønmental Impacts of Mining Activities (J.M. Azcue, editor). Springer, Berlin.

Petit, S., Caillaud, J., Righi, D., Madejová, J., Elsass, F. and Köster, H.M. (2002) Characterization and crystal chemistry of an Fe-rich montmorillonite from Ölberg, Germany. Clay Minerals, 37, 283-297.

Quesada, C. (1990) Precambrian successions in SW Iberia their relationship to Cadomian orogenic events. $\mathrm{Pp}$. 353-362 in. The Cadømian Orøgeny (R.S. D'Lemos, R.A. Strachan and C.G. Topley, editors). Special Publication, 51, Geological Society, London.

Reyes, A.G. and Read, S. (2002) Nontronite formation in

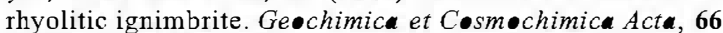
(15A), A635, Suppl. 1

Russell, J.D. and Fraser, A.R. (1994) Infrared methods. Pp. 11-67 in: Clay Mineralıgy: Spectroscopic and Chemical Determinative Methods (M.J. Wilson, editor). Chapman \& Hall, London.

Savin, S.M. and Epstein, S. (1970) The oxygen and hydrogen isotope geochemistry of clay minerals. Geechimic et Cosm•chimic Acta, 34, 25-42.

Shenk, K. and Armbruster, T. (1985) Beidellite-nontronite, an alteration product of cordierite in the rhyolite from Torniella (Tuscany, Italy). Neues Jahrbuch für Mineraløgie Monatshefte, 9, 385-395.

Sheppard, S.M.F. and Gilg, H.A. (1996) Stable isotope geochemistry of clay minerals. Clay Minerals, 31, 1-24.

Singer, A. and Stoffers, P. (1987) Mineralogy of a hydrothermal sequence in a core from the Atlantis II Deep, Red Sea. Clay Minerals, 22, 251-267.

Singer, A., Stoffers, P., Heller-Kallai, L. and Szafranek, D. (1984) Nontronite in a deep-sea core from the South Pacific. Clays and Clay Minerals, 32, 375-383.

Ueshima, M. and Tazaki, K. (2001) Possible role of microbial polysaccharides in nontronite formation. Clays and Clay Minerals, 49, 292-299. 